\title{
Mitigating The Financial Burden Of The State To Maintain Convicts In Prison Based On Local Wisdom
}

\author{
I Ketut Widia \\ \{ketut_widia@yahoo.co.id\} \\ Magister of Law, Postgraduate Program, Universitas Warmadewa
}

\begin{abstract}
In Indonesia, every year always build a prison with very expensive costs. Legally and economically, this is desperate, because it is indicative of the failure of legal work in the community and the cost incurred by the state every day reaches three billion rupiahs to guarantee the life of prisoners in prison. A fantastic amount because it is used to look after criminals. Empirical data shows, many criminals will be worse after have ever been in prison. For this reason, there is a big idea to resolve legal issues in the community, is through customary law, because historically the traditional solution is the personality of the nation and more guarantees a sense of justice, aside to meet the principles of litigation fast, cheap, and transparent. This study intends to identify the types of cases that can be resolved by custom in the community and to discover the best way to implement the procedural law of customary justice in order that a sense of justice for the community is realized. Empirical legal research is the type of research that will be used. Theories used to analyze the issues are social engineering theory and legal system theory. The results of the study indicate that mediation is very deserved to done through custom law to resolve the problem in community. Regarding the procedural law of customary justice, all kinds of problems are resolved by deliberation to reach consensus through mediation guided by the chief of the tribal council.
\end{abstract}

Keywords: prisoners, mediation, customary criminal law, customary law

\section{Introduction}

If studied more deeply, regarding the various types of crimes that arise and often occur in prisons, there is a single cause, namely the overcrowding of prisons. On average, each prison in Indonesia is almost overcapacity, which exceeds one hundred per cent. The illustration is that if a prison has the capacity to accommodate 500 people, the number of convicts in prison is up to 1,000 people. It could be imagined how full and crowded it is in a prison that is controlled by a very limited number of officers. Not only that, every day the state must spend up to hundreds of millions of rupiah just to repair the prisons damaged caused by riots committed in the prison. In addition, other state expenditures are the costs used to search for inmates who escaped from prison due to various causes, which amounted to hundreds of millions of rupiah each time a convict escaped from the prison. Therefore, emerging the ideas as an effort to mitigate the number of convicts in prisons based upon customary law shall 
certainly not to be underestimated, besides because historically the Indonesian people have applied mediation or problem solving based upon traditional basis since the old days of the kingdom, so that it has become a part of the efforts to resolve cases customarily. Resolving the problems through customary law is actually a manifestation of deliberation to achieve consensus which is mandated in the Pancasila as the basis of the country and the view of the Indonesian people.

The illustration above is an only partly overview of the prison conditions throughout Indonesia. If a more detailed study is carried out, the conditions and number of convicts in the prison could exceed the amount presented, so that the situation results in frequent riots that cause significant casualties and property losses. Thus the idea to reconcile the people who stumble over criminal cases is very feasible to study and conduct.

Some latest related studies conducted by several researchers who conducted the similar study, they are [1], [2], [3] and [4]. The purposes of the study conducted by [1] is to give an alternative approach that can be used to account for murder crimes in accordance with the legal formal criminal code and material criminal code. The finding showed that police investigation must not be discontinued dispite that adapt law has settled the case. Chapter 102 article (1) of Act No.8 of 1981 says that an investigator who has knowledge, receive a report of a crime act must immediately conduct a necessary investigation. Furthermore, chapter 106 of the same act also says the same thing. In addition to this, chapter 14 article (1) letter $\mathrm{g}$ of act No. 2 of 2002 on Police of The Republic of Indonesia Stipulates that the police of the Republic of Indonesia have the duty of conducting an investigation and research of any kinds of criminal code and other legislation. Moreover, [2] conducted the research about the efforts to reduce the density of prisoners in prison in Indonesia nowadays and the efforts to reduce the density of prisoners in prison in Indonesia in the future. The finding of this study showed that comparative studies of efforts to reduce prisoner density with the Good Time Allowance model in foreign countries include the laws of the state of Wyoming (US), the Republic of Philippines, Montana (USA). Good Time Allowance model is a reduction in serving time by doing good work, can provide motivation to prisoners by doing a good job to commit to be good with respect to reducing the time of serving a criminal. Besides the study conducted by [1] and [2], the similar study also conducted by [3] which focused on to explain the criminal law policy adopted in the PLH (The Principle of Environmental Management) Qanun and to explain the Qanun for environmental management could adopt adopting the principles of local wisdom in Aceh. The results of this study showed that the PLH (The Principle of Environmental Management) Qanun made local wisdom a part of the substance of the Qanun. Local wisdom that must be adopted is diyat or dheit and sayam and Suloh (peace) as a dispute resolution technique that can be considered in resolving environmental disputes in Aceh. [4] conducted the study which aims to find out the role of customary law in the resolution of criminal acts. The finding of this study showed that the process of settlement customs violations carried out by traditional institutions that act as customary justice be gradual manner. In case of violation of customs which are lightweight (small donation) is usually customary court proceedings start after a report from the litigants either in writing or verbally, then if the customary court convened and the decision has been generated, then the litigant parties are given time to think for 3 days to determine the attitude of accepting or rejecting.

Based on the background and the relevant studies above, thus it can be stated that this study is different from the previous study since this present study aims to identify the types of criminal cases that may be resolved through customary mediation so that the suspect is not imposed a prison sentence and to discover the standard procedure in solving problems through customary law so that it maximally fulfils a sense of justice for the parties to the dispute. 


\section{Methods}

The type of research used in this study is empirical legal research or socio-legal research. The study was conducted in Bali Province by taking four prisons in Bali as the subject of research, they are Kerobokan Prison in Badung District, Gianyar Prison in Gianyar District, Jemberana Prison in Kota Negara, and Buleleng Prison in Singaraja.

\section{Results And Discussion}

Building on the purposes and the background of the study above, thus this study derived the results of the study which based on the analysis. The results of this is described in the following explanation.

a) Overview of Prisons in Indonesia

Regarding the overcrowding of prisons in Indonesia, This can be proven through the data presented below.

1) The Prison of Pekan Baru Riau with a capacity of 330 people but filled with 1050 convicts.

2) The Prison of Tanjung Gusta Medan with a capacity of 1054 people was filled with 2600 convicts.

3) The class 2 prison of Labuan Ruku, Batu Bara Regency, North Sumatra with a capacity of 251 people but filled with 867 convicts.

4) The Class 2A Prison of Kerobokan has a capacity of 360 people but was filled with 1100 convicts.

5) The Malabero Bengkulu Penitentiary with a capacity of 250 people was filled with 758 people

6) The class $2 \mathrm{~A}$ prison of Jambi with a capacity of 380 people was filled with 1700 convicts (Source: Tempo.co.id May 8, 2017 edition accessed November 17, 2017).

The illustration above is a general overview of the prisons condition throughout Indonesia, if a more in-depth study is carried out, the number of excess convicts can be more than what is presented so that as to result in frequent riots that cause fatalities and property in vain. Thus the idea of reconciling people who stumble criminal cases is very feasible to be appreciated and carried out. This has become crucial especially in order to mitigate the number of convicts in prison. The phenomenon of the excess capacity of prison buildings turned out to occur almost evenly throughout Indonesia. All 526 prisons in Indonesia only have cargo with 123,000 people, but all of them are filled with more than 231,000 prisoners.

Nationally there are several Penitentiaries in Indonesia that have a number of convicts exceeding a capacity of more than $400 \%$. they are:

1) Detention centre in Takengon (excess capacity up to $597 \%$ ),

2) Detention centre in Banjarmasin (excess capacity up to 595\%),

3) Detention centre in Tarakan (excess capacity up to $543 \%$ ),

4) Detention centre in Bandar Lampung (excess capacity up to 528\%).

5) Langsa Detention centre in Aceh (excess capacity up to 502\%),

6) Kotabaru Detention centre in South Kalimantan (excess capacity up to 494\%),

7) Labuhan Ruku Detention centre in North Sumatra (excess capacity up to $490 \%$ ),

8) Dumai Detention centre in Riau (excess capacity up to 458\%), and

9) Kupang Detention centre in East Nusa Tenggara (excess capacity up to $430 \%$ ). 
10) Kerobokan prison in Bali exceeds the capacity of up to $460 \%$.

Therefore, the existence of ideas and hopes for an option to settle problems traditionally and impose other penalties other than imprisonment, those are: social work penalty and fines is necessary to be appreciated and tried to be carried out on a legal basis through efforts to amend the law.

Considering that the problem keeps repeating from year to year, of course, the idea to settle criminal cases by customary law or deliberation should not be underestimated. This is because the customary justice system is actually not something newest in Indonesian society. In contrast, the prison system adopted by the Indonesian government today is a western system originating from the Dutch and British who once colonized Indonesia. Regionally, the conditions of prisons in Bali are generally not much different from the conditions of prisons in general in Indonesia. The description below is the condition of several prisons in Bali.

b) The Condition of Kerobokan Penitentiary in Badung District

The Kerobokan Penitentiary located in Badung District includes a very crowded prison with its inmates. Various criminal cases always occur in this prison. Starting from fights between the convicts, drug trafficking, escape of prisoners, to discrimination and buying and selling luxury facilities in prisons. Regarding the alleged discrimination in this prison, investigative efforts have been made. However, the results have not been able to satisfy the sense of justice for the community.

To overcome this problem in Kerobokan prison, authorized agency transfers convicts to various prisons in Java. It was realized that the inmates' transference to Kerobokan Prison urged to be done immediately. This prison is no longer eligible. The registration room is gone. The facilities were no longer adequate and this even had the potential to trigger dissatisfaction among prison inmates. Nevertheless, the evacuation will not be carried out in compelling ways and it will not give priority to certain groups because it is feared that it will trigger dissatisfaction among other convicts in the prison. Quantitatively, Kerobokan prison is inhabited by 1,015 convicts or far exceeding the capacity of only 300 people. Of that number, 60 of them, men and women, are from 17 different countries. This means that the Kerobokan prison has indeed been overloaded by inmates.

c) Conditions of Negara Penitentiaries in Negara City

Negara Penitentiary which is located on the west side of Negara city is a small prison or Class B detention. There are not too many inmates, but it can still be said to be excess because it exceeds the capacity it should have. In order to prevent the occurrence of undesirable things happening in prison Negara, the Police routinely conduct surveillance by conducting raids on convicts of prison inmates.

Related to the state detention centre conditions, according to Jembrana deputy police chief AA Gde Rai Laba is in an overload condition, which should have been filled by 90 people, is now inhabited by 105 prisoners, with a total of 47 officers.

d) Conditions of Tabanan Penitentiary in Tabanan

The condition of the Tabanan Penitentiary, Bali, is crowded because the number of convicts and detainees has reached 120 people or exceeds the capacity that can only accommodate 47 people. "Now it is overloaded and overcrowded because the number of inmates and capacity is inadequate," said Head of Tabanan Prison Kristiyanto, BcIP, SH in Tabanan. Even so, Tabanan Penitentiary will continue to provide guidance and good monitoring for inmates both convicts and detainees. 


\subsection{The Existence of Customary Justice in the Community}

Providing the understanding to the community, especially to traditional village leaders that deliberation to reach consensus in resolving problems in the community had been always done before the Dutch legal system with a prison sentence model is implemented. Before the Dutch colonized Indonesia, there were no prisons in Indonesia because most of the legal cases and community problems were resolved by deliberation to reach consensus in accordance with the values of local wisdom. The big idea of this study is making an effort to develop local law or customary law to be able to reach and accommodate every problem that exists in the community to be resolved by deliberation to reach consensus so that the problems do not reach the court area which has proven to be costly, time spent in court very long, and the most important thing is not fulfilling the sense of justice that grows and develops in the community. Based on the results of the study, there are several legal cases that can be resolved by custom to avoid the perpetrators of the crime get into prison, those are:

a) Theft or embezzlement of funds with a value of no more than ten million rupiahs.

b) Humiliation, defamation, adultery which is still classified as a crime with a pure complaint offense.

c) Corruption with a value of under one hundred million rupiahs.

d) One on one fights or mass fights.

e) Murder, which can only be carried out as long as the victim's family forgives the perpetrator and the perpetrator confesses and apologizes and pays compensation, burial costs, and covers the cost of living for the victim's family.

f) Cases of traffic accidents.

g) Criminal acts of sexual harassment.

h) Domestic violence.

i) Divorce cases.

j) Cases of distribution of inheritance that often lead to conflict and violence to acts of murder.

In contrast to crimes which include extraordinary acts such as drug abuse, terrorism and corruption in the amount of more than one hundred million rupiahs, it is still being processed legally until the perpetrators of this type can get into prison with maximum punishment.

\subsection{Procedures for Customary Deliberation}

The procedures for resolving the crimes in the customary method are generally done through deliberation to reach consensus. The parties who litigated or the victims represented by their families and the perpetrators were confronted at the local village office with escort by a local customary security unit called Pecalang. If it is deemed necessary to require security assistance by law enforcement officials, the village may ask for assistance from the Indonesian National Police and the Indonesian National Army as security during a village court hearing

The local village elders, or maybe called with other different names in different villages, are given the authorities that are explained below.

1) To accept a report from the community both individually or in a group.

2) To conduct important actions in the place where the disputes take place.

3) To stop an accused and verify their identity.

4) To carry out arrests, detention and searches, and if deemed necessary to confiscate evidence relating to criminal acts.

5) To make arrests and confiscate letters.

6) To take a photograph of someone. 
7) To call people, both as suspects and as witnesses, to blunt information about their testimonies.

8) If needed, to bring in experts in relation to case investigations.

9) If the evidence is deemed not fulfilling, the local village leader may stop the investigation and investigation.

10) To do actions required insofar as it does not conflict with the prevailing norms in the community.

The types of customary sanctions that can be imposed include sanctions whose emphasis lies in giving sincere forgiveness by victims of traditional offenses and compensation by the perpetrators of the customary offenses to the victims or to the families of the victims. If the peace effort through the customary court does not reach an agreement, the solution is immediately transferred to the police as an official who has the authority to carry out investigations and has high force because he has the instrument for that. In other words, the legal process will take place in accordance with the provisions of the Criminal Procedure Code which lead to a decision where the perpetrators are given a prison sentence. If this happens, it means that the idea of reducing the number of prisoners in prison cannot be realized. However, whatever the risks posed, the idea of resolving criminal cases in a customary manner should be given a good appreciation, because it has been proven that such methods are able to solve problems so that the perpetrators of the crime can avoid getting into prison which is highly feared and occur high costs that must be borne by society and the state.

\section{Conclusions}

Taking into account the problems formulated, there are two conclusions that can be drawn that 1) cases in the community that deserve to be resolved customarily with deliberation to reach consensus are crimes that do not constitute a crime with the threat of imprisonment of up to five years in prison. For example, cases of traffic accidents, even though they may cause the lives of victims, as long as the perpetrators want to provide compensation; cases of fraud and embezzlement in a value of no more than one hundred million rupiah; cases of fights, vandalism, humiliation, defamation, sexual harassment, domestic violence, divorce, and so on. If the case is large and is very dangerous to the community in general such as the crime of corruption, terrorism and narcotics, it certainly shall be resolved through the national criminal justice mechanism. 2) regarding the procedure for resolving cases in a traditional manner, in general, the emphasis is on deliberation efforts to reach consensus by being mediated by local elders and accompanied by law enforcement officials, especially the police.

\section{References}

[1] F. M. Yusuf, "Tindak Pidana Pembunuhan Yang Diselesaikan Secara Adat Yang Tidak Sesuai Dengan Perundang-Undangan (KUHP dan KUHAP) ( Study Kasus Desa Ture dan Desa Lubuk Ruso Kecamatan Pemayung di Kabupaten Batang Hari)," J. Ilm. Univ. Batanghari Jambi, vol. 9 , no. 2, 2009.

[2] G. P. Mulyono and B. N. Arief, "Upaya Mengurangi Kepadatan Narapidana Dalam Lembaga Pemasyarakatan Di Indonesia," J. Law Reform, vol. 12, no. 1, p. 1, 2016.

[3] M. Natsir and A. Rachmad, "Penetapan Asas Kearifan Lokal Sebagai Kebijakan Pidana dalam Pengelolaan Lingkungan Hidup di Aceh,” J. Magister Huk. Udayana (Udayana Master Law Journal), vol. 7, no. 4, p. 468, 2018.

[4] I. Hidayat, "Peranan Hukum Adat Dalam Penyelesaian Tindak Pidana," pp. 9-23, 2017. 